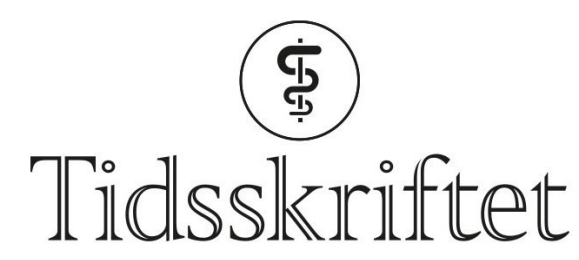

DEN NORSKE LEGEFORENING

\title{
Blikkets kraft
}

ESSAY

\section{STIG HESKESTAD}

E-post: stig.heskestad@lyse.net

Stig Heskestad er pensjonert psykiater og tidligere sjeflege ved Jæren DPS.

Forfatteren har fylt ut ICMJE-skjemaet og oppgir ingen interessekonflikter.

Da fysiske møter ble byttet ut med digitale, oppdaget vi på nytt betydningen av blikkontakt.

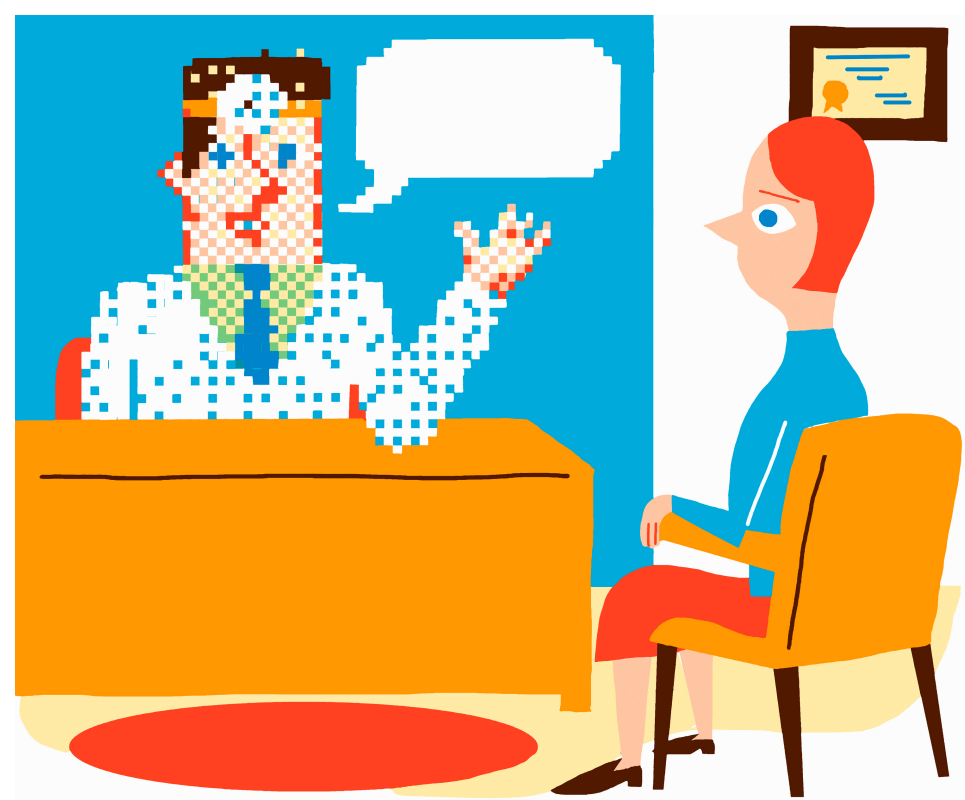

Illustrasjon: Phil Marden / NTB

Når mennesker møtes, er blikket møtepunktet. Leger som daglig møter en rekke forskjellige mennesker, gjør vel i å reflektere over blikkets betydning. Journalist Egil Olav Aune skrev etter et legebesøk (1):

«Mens jeg ble spurt om de merkeligste ting, så legen forbi meg, festet blikket på et punkt bak ryggen min, et sted som egentlig ikke finnes - i hvert fall ikke når det sitter et menneske imellom. Dette handler om et problem. At legen ikke har tid til å se meg inn i øynene lenger. Gi meg legen min!»

Lyrikeren Stein Mehren så det $\operatorname{slik}(2)$ : 


\section{Bønn (ikon)}

Vi ber ikke om utskrifter, forklaringer, diagnoser, prosedyrer

Vi ber ikke engang om overbevisninger

Vi ber om å bli sett av en annen

Vi ber om et ansikt

\section{Blikkets betydning}

Ordet blikk stammer fra det tyske ordet Blitz, som betyr lyn, som igjen er avledet fra det germanske ordet blika, som betyr strålende (3). Ordet rommer altså noe brått og flyktig som samtidig er kraftfullt og utstrålende. Det mest kraftfulle blikket er når pupill møter pupill. Dette møtet er så sterkt at det vanligvis bare utholdes noen sekunder i taushet.

Ordet blikk har en rekke konnotasjoner, nyanser og metaforer knyttet til seg: det forsonende, varme og interesserte blikket, det fiendtlige, harde, stikkende, kritiske og drepende blikket, det redde, usikre og bedende blikket, det flyktige og flakkende blikket, det skamfulle og unnvikende blikket, det dvelende og flørtende blikket og det åpne blikket.

Øyet fungerer både som et kamera og en lyskaster, det både tar imot og utstråler. Et blikk handler således om mye mer enn å se. Det er et signal til andre mennesker - et signal som kan oppfattes som en invitt, en korreksjon, et spørsmål og mye mer. Vi lytter også med blikket. Foredragsholdere henter inspirasjon fra lyttende blikk. Og vi peker med blikket.

I 2018 introduserte Språkrådet verbalet blikking (4). Å bli blikket brukes av ungdommer som uttrykk for nedvurdering eller mobbing og kan være påskudd for å ta igjen med vold.

\section{Det første og det siste}

Hos det nyfødte barnet leter mor etter den første mentale kontakten i blikket. Når mors og barns øyne møtes, oppstår den første relasjonen i barnets liv. Under amming ser vi at barnet er sulten også på relasjonell kontakt og søker derfor morens blikk. Den første tiden er linsen til babyens øye innstilt nettopp på avstanden til morens ansikt når den blir diet (5). Når blikkontakten er etablert, kan den utholdes over lang tid det første leveåret. I denne kontakten skjer en sammensmelting, og barnets gryende bevissthet holdes sammen av mors blikk. Samtidig etableres en kanal for veiledning inn i verdenen.

Når livet ebber ut og kreftene er så svake at selv stemmen svikter, er gjerne den siste rest av kontakt i blikket - til dagen da «blikket brister». Blikket blir det siste farvel.

\section{Blikkets kulturhistorie}

Blikkets sentrale funksjon forklarer hvorfor de fleste kulturer markerer øynene med kunstige farger eller ved å dryppe plantesaft i dem for å lamme irismuskelen og utvide pupillene. 


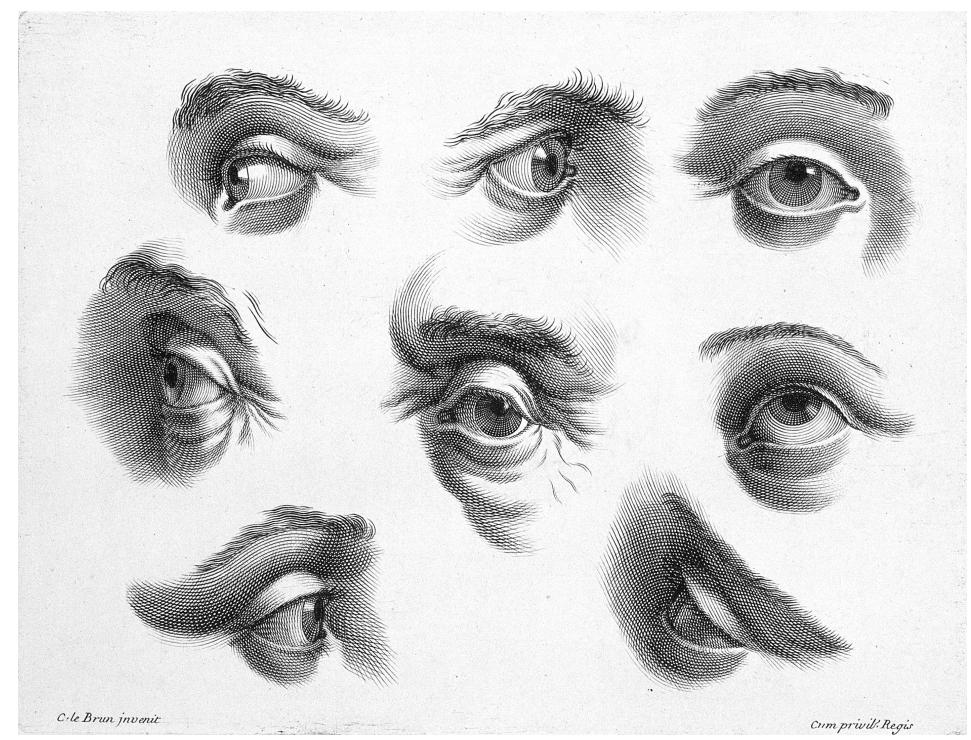

Uttrykksfulle øyne tegnet av Charles Le Brun (1619-9o). Illustrasjon: Welcome Collection

Fordi blikket er så viktig biologisk og sosialt, blir det vesentlig å kontrollere blikket. Alle samfunn har uskrevne regler for hvor lenge det er tillatt å se på et annet menneske. Samfunnsklasse og sosial status spiller en stor rolle, og i flere kulturer forventes det at den sosialt svakeste bryter blikkontakten først.

Den etiske handlingsimpulsen springer ikke ut fra verdidokumenter eller etiske regler. Den begynner med blikket

Det onde øyet innebar i folketroen at man kunne gjøre skade ved hjelp av blikk, en evne man trodde enkelte personer hadde. For å beskytte seg ble det brukt amuletter eller besvergelser. Så sent som for 100 år siden var det vanlig også i vårt land at gravide kvinner ikke måtte forse seg, dvs. de måtte unngå sterke og spesielle synsinntrykk. Det moren så, kunne virke inn på barnet. Å se på en hare kunne gi hareskår hos barnet, å se på en skjeløyd person kunne gjøre barnet skjeløyd.

\section{Tolking av blikk}

Kontrasten mellom iris med pupillen og den hvite sklera er særegent ved menneskets øye. Dette gjør det lettere for andre å registrere blikkets retning. Gjennom øyekontakt skjer en automatisert og hurtig avlesing av andre menneskers blikk (6) - ser de meg eller ikke? Avhengig av kontekst registreres også mental status ved blikkontakt. Er vedkommende trett eller trist eller inviteres det til videre kontakt? Denne menneskelige evnen antas å spille en sentral rolle i det daglige sosiale samspillet.

Det er velkjent at pupillen utvider seg ikke bare i mørket, men også ved sterk utrygghet og angst. Når det i en psykiatrisk avdeling rapporteres at pasienten er mørk i blikket, kan det være tegn på høyt stressnivå. Pupillstørrelsen påvirkes også av medikamenter og rusmidler.

Ansiktet og mimikken som ledsager blikket, er avgjørende for tolkingen av blikket. Blikket kan avskjermes bak øyelokk og tilsløres av tårer. Tårer er sterke følelser som presser seg fram til overflaten - sinne, sorg eller glede. Hvis det ikke bare er tette tårekanaler!

Oppspilte øyenlokk og hevede øyenbryn gir også viktig informasjon. En gjentatt bilateral blunking tolkes gjerne som nervøsitet eller øyeirritasjon, mens en viljestyrt ensidig blunking er en kraftfull invitt til kontakt.

\section{Omsorgsblikket}

Den serbisk-amerikanske performancekunstneren Marina Abramović utforsket blikkets betydning i forestillingen The Artist Is Present i Museum of Modern Art i New York i 2010 (7). Over en tremånedersperiode satt hun i en stol og inviterte publikum til å sette seg i en stol vendt mot henne på to meters avstand. Det var ingen verbal eller fysisk kontakt. Hver 
person kunne sitte overfor henne så lenge de ønsket. De skulle ha øyekontakt, men det var ikke tillatt for publikum å berøre henne eller snakke til henne. I til sammen 736 timer satt Abramović og betraktet 1500 mennesker. Tilstrømningen til forestillingen oversteg forventningene. Den siste dagen ble det registrert 17 ooo tilskuere.

\section{Illustrasjon: Derek Bacon Unplugged / NTB}

Abramović forteller i sin biografi at hun erfarte umiddelbart at menneskene som satt mot henne, ble sterkt beveget, og hun opplevde en tilknytning til hver person (7, s. 308-21). Følelsen av gjensidig ubetinget kjærlighet overfor fremmede var noe av det mest utrolige hun noensinne hadde opplevd.

I personlige relasjoner uttrykkes en maktposisjon gjennom ordvalg og kroppsholdning, men ikke minst gjennom blikket

Kari Martinsen, norsk pioner innen sykepleiefaglig teori, hevder at det er en allmennmenneskelig egenskap å ha blikk for andres sårbarhet (8). Det krever ikke fagkunnskap eller etikkompetanse. Hun viser bl.a. til den vestlige medisinens grunnfortelling om den barmhjertige samaritan, nedskrevet av legen Lukas i Lukasevangeliet (9). En mann ble utsatt for blind vold og forlatt halvdød. En levitt (prest) passerer offeret uten å stanse. Så kommer en samaritan, en utlending, forbi. Da han får se mannen, får han inderlig medfølelse, som leder til praktisk omsorg. I blikket til samaritaneren vekkes sterke følelser, på gresk splanchniste, som betyr følelser som griper tak i innvollene. Martinsen kaller dette «å se med hjertets øye». Hun vektlegger at omsorg er relasjonell, handlingsorientert og moralsk. Blikket utløser en omsorgshandling når det gir en emosjonell resonans. Emosjonen beveger. Det eksistensielle blikket sier: Du er mitt medmenneske. Det er et blikk som ser mennesket, får et glimt av sjelen og utløser medfølelse.

Ansiktet og blikket som vendes mot andre, var et hovedtema i forfatterskapet til den jødiskfransk-litauiske filosofen Emmanuel Lévinas, som skriver om «trancendensens stråleglans i den andres ansikt» (10). Stråleglansen oppstår i blikket når man ser den andre som en enestående og uerstattelig skapning. Her har etikken sin kilde, ifølge Lévinas. Den etiske handlingsimpulsen springer altså ikke ut fra verdidokumenter eller etiske regler. Den begynner med blikket!

\section{Blikk og makt}

Den franske filosofen og idéhistorikeren Michel Foucault reflekterer i boken Klinikkens fødsel over det kliniske blikket (11). Dette blikket observerer, men intervenerer ikke. Det er taust 
og ubevegelig. I tidligere bøker har han beskrevet hvordan det observerende blikket anvendes for å påvirke og disiplinere folks atferd, særlig innenfor maktsystemer som fengselsvesen og psykiatriske institusjoner.

Gjennom blikket formidles balansen mellom nærhet eller distanse, involvering, overinvolvering eller likegyldighet

I personlige relasjoner uttrykkes en maktposisjon gjennom ordvalg og kroppsholdning, men ikke minst gjennom blikket. Personer veksler blikk for å bekrefte enighet, men det kan også brukes som et hint mot en tredje person. Har du, som jeg, opplevd å bli låst fast av en annens blikk - en som vil overbevise deg eller vil ha deg på sitt parti? Narsissisten jakter på andres blikk, særlig mennesker med status og betydning. Hensikten er primært selv å bli sett og beundret (12). Her lurer forførelsen.

\section{Blikk og avmakt}

I psykiatrisk journal hører en bemerkning om blikkontakt med. For enkelte oppleves blikkets berøring så sterk at de må beskytte seg. Dette er et sentralt problem for mennesker med sosial fobi. For dem er det viktig å unngå situasjoner hvor de er gjenstand for andres granskende blikk. Mennesker med alvorlige mentale lidelser kan være svært sensitive for blikk og ansiktsuttrykk og tolke dette inn i sin forstyrrede tankeverden.

Å bli lagt merke til kan være både godt og ubehagelig, men å bli oversett er entydig negativt. Å la være å se på et annet menneske når dette er forventet, oppleves avvisende eller ydmykende. Det var kanskje slik forfatteren Thorvald Steen, som har en progredierende muskelsykdom, opplevde det som barn (13): «Min far så ned da han så sykdomstegnene. Min mor snudde seg vekk.»I samme intervju legger Steen til: «Det som blir tydeligere for meg er andres blikk. Aller størst merket jeg det da en venn av meg så meg for første gang i rullestol og lot som han ikke så meg.»

Leger står daglig i asymmetriske relasjoner med pasienter og pårørende som ber om lindring, råd og forsikringer. Legen tolker pasientens blikk og pasienten tolker legens blikk. Gjennom blikket formidles balansen mellom nærhet eller distanse, involvering, overinvolvering eller likegyldighet. Pasienten er sensitiv for legens blikk, en evne vi alle har med oss fra barnsben av og som forsterkes i sårbare møter. I disse møtene er det avgjørende at legen er bevisst på kraften i blikket og mestrer både det observerende blikk og kan se med hjertets øye.

LITTERATUR:

1. Aune EO. Gi meg legen min. Vårt Land 21.02.2011.

2. Mehren S. Bønn (ikon). I: Nattmaskin. Oslo: Aschehoug, 1998.

3. Caprona Yd. Norsk etymologisk ordbok. Oslo: Kagge forlag, 2013.

4. Språkrådet. Blikking. https://www.sprakradet.no/Vi-og-vart/hva-skjer/Aktuelt-ord/blikking/ Lest 10.7.2020.

5. Holm M. Ser barnet mitt dårlig?

https://www.helsenett.no/208-sykdommer/oye/oye/16367-ser-barnet-mitt-darlig.html Lest 10.7.2020.

6. Macrae CN, Hood BM, Milne AB et al. Are you looking at me? Eye gaze and person perception.

Psychol Sci 2002; 13: 46o-4. [PubMed][CrossRef]

7. Abramovic M. Walk through walls. A Memoar. Penguin Books, 2016.

8. Martinsen K. Øyet og kallet. Bergen: Fagbokforlaget, 200.

9. Evangeliet etter Lukas, kap. 10. I: Bibelen. Oslo: Bibelselskapet, 2011.

10. Levinas E. Underveis mot den annen. Oslo: Vidarforlaget, 1998. 
11. Foucault M. Klinikkens fødsel. København: Hans Reitzels forlag, 2000.

12. Torgersen S. Personlighet og personlighetsforstyrrelser. Oslo: Gyldendal Akademisk, 2008.

13. Skårderud F. Thorvald Steen skriver om egen sykdom. Aftenposten 12.8.2017.

https://www.aftenposten.no/kultur/i/PV1Be/thorvald-steen-skriver-om-egen-sykdom-min-far-saa-ned-d a-han-saa-sykd Lest 15.6.2020.

Publisert: 21. oktober 2020. Tidsskr Nor Legeforen. DOI: 10.4045/tidsskr.20.0462

(C) Tidsskrift for Den norske legeforening 2020. Lastet ned fra tidsskriftet.no 